for it is the last place in the Indian Ocean where island life can be studied in isolation.

The expedition landed at the west island, where there has been a settlement since 1888, and from there made excursions to the south and north, and, together with parties from the Ministries of Defence and Public Building and Works, to the east end of the atoll. The aim was for each member to become acquainted with as many habitats as possible. The eastern end proved to be the area of greatest ecological interest. It has the greatest concentration of giant land tortoises, Testudo gigantea. There are apparently more than 10,000 of these tortoises on Aldabra; elsewhere they are only found in the Galapagos Islands. The eastern end has also the greatest number of frigate birds, as many as a thousand birds could be seen hanging above one of the fresh water pools which attract them. The main breeding area of these birds is in the middle island where hundreds of thousands were seen nesting.

This survey work is being continued by four scientists and two technicians of the Royal Society party who remained on Aldabra to carry out the second phase of the expedition. If the Ministry of Defence project is not implemented, a long term thorough ecological survey will be planned; if the project goes ahead the expedition will make the fullest possible ecological survey before the ecology of the atoll is changed by the construction work.

Aldabra has remained untouched because it is so inhospitable to man; the terrain is difficult and apart from rain there is very little drinking water. The proposed developments will be extensive, and the whole ecology will suffer. When construction begins the weeds which are associated with settlements, and which are now contained by the native vegetation, will spread through Aldabra. There will be a flow of foreign weeds and invertebrates into the islands, and the feral mammals now confined to the south and west islands will spread throughout the atoll. When the cats find the flightless rails these birds will not last very long. The danger is not, however, of large scalc extinction; the RAF would make efforts to preserve the giant tortoise and flightless rail, which in any case can be preserved in zoos. The inevitable consequence of construction work will be the destruction of the integrity of an unspoiled island ecosystem. This is the last remaining ecosystem of its kind in the Indian or Pacific Oceans, and that for the Royal Society is reason enough for preserving it.

\section{Money for Chemists}

THe Chemical Society is appealing to its members for money. This is not because of careless accountancyin fact the society seems to have been scrupulously careful-but is one result of a move which the society plans to make to the rooms occupied until recently by the Royal Society in Burlington House. The Royal Society itself has moved to Carlton House Terrace, and most of the rooms left empty have been offered. to the Chemical Society rent free by the British Government. The snag is that the move will be expensive-the society estimates that it will need $£ 300,000$ to adapt and furnish the new rooms, build a new publications warehouse at Letchworth and share the cost of a new lecture theatre in Savile Row. By what it describes as prudent husbanding of its re- sources, the society has saved $£ 125,000$, and is now appealing to its members, to the chemical industry and to charitable trusts for the extra $£ 175,000$.

Chemists who feel that this is an expensive move should reflect that the new rooms will enable the society to group together staff previously distributed all over London. It will also provide a council room and a much larger library. They might also be reminded that it has cost the Royal Society $£ 863,000$ for its move to Carlton House Terrace. $\$ 250,000$ was supplied by the Government, and an equal sum by the Nuffield Foundation, but much of the remainder is still outstanding. Ominously for the Chemical Society's hopes, an appeal to fellows of the Royal Society has not so far produced everything the organizers hoped for. And gratitude to the Government for its generosity in supplying accommodation should perhaps be tempered by the thought that once there were splendid hopes for a home for scientific societies in a science centre on the South Bank. It is a long time since that idea was last heard of.

\section{Temptations of Science}

THE British preoccupation with the need to persuade young people into science and engineering, but particularly the latter, was continued last week by the Research and Development Society, which devoted the second of its one-day symposia to the subject. Adults, at least, are prepared to take the subject seriously, and 150 turned up at Imperial College to listen to a panel of speakers which included many of those whose names are now associated with the definition of various aspects of this problem-Professor Michael Swann, for example, and Mr G. S. Bosworth, Director of Personnel at the English Electric Company. Mr Bosworth was strong in his statement that "technology is not a second-rate science". To pretend otherwise is now, of course the most sure way in which a man can lose his public reputation. But Mr Bosworth also said that engineers are too often diverted from the objectives by irrelevant details in atomic theory, and that industry often mistreats those whom it recruits so that they hurry back to the "world of the PhD". Mr D. A. Head, from the aero-engine division of Rolls Royce, took the line that, however the difficulties of attracting scientists into industry have arisen, only industry can handle the problems thus created, which means that companies must put recruits into the right jobs and make sure that they know about their prospects of promotion.

The symposium seemed to agree about the shortcomings of education in British schools and universities. For one thing, there was a general complaint about early specialization, one of the consequences of which is the alleged reluctance of narrowly educated people in industry to change from one kind of job to another. On the whole, those attending the conference took the view that specialization should be postponed until 18. There was also a general feeling that science courses at universities should be broadened so as to provide students with an appreciation of other kinds of studies and of social problems of various kinds. One speaker went so far as to say that the British educational system is designed to produce "cultured gentlemen", with the result that trained scientists consider that collaboration is a kind of cheating, that engineering is inferior and that the profit motive is even worse. 
Yet teamwork, technology and business sense are essential for the survival of the British economy.

But what if you cannot even bring the horse to the water, let alone persuade him to drink properly ? The symposium depressed itself with speculation about the reasons why young people may now be reluctant to go in for science and technology. Again there seemed to be general agreement that the young are infected with a "new fatalism" and have no vision of a golden future to which science and technology may contribute and no inkling of the enthusiasm which professional scientists have for their work. It was all good gloomy stuff. One of these days something may be done about it.

\section{Instant Teachers}

How long does it take to turn a student of the humanities into a science teacher? Three years is the answer given by Nottingham Regional College of Technology. In its new Department of Education, Nottingham is basing its acceptance of candidates for its three year Certificate of Education course in science teaching on general ability and interest in science teaching as well as academic qualifications in science. Thus if a candidate can demonstrate his ability in other subjects and his interest in science teaching, the college will accept him even if he does not know one end of a thermometer from the other.

Because of the shortage in applications from science candidates to teacher training colleges and universities, the department has decided not to compete for pure scientists but to offer Applied Science and a second opportunity to those who opted for the humanities instead of science at school. As the courses are designed for the Nuffield programme of science teaching, where a feel for the subject is much more important than facts, it is hoped that general ability will make up for any lack of specific knowledge.

The courses will tend towards either Biological Sciences or Physical Sciences and an Engineering course is under discussion. The students of the physical seiences will spend four terms working on American courses, which start from first principles for beginners but allow scientists to be rapidly directed into more profitable work. The teaching scheme is based on individual study rather than lecture programmes, and tutors will make much use of written material, acting as directors of study and tailoring the work to each student's needs. Students will also be able to take short courses from a range which will include Computer Science, Chemical Technology, Building Science, Food Science, Materials Science and Mechanical Engineering. These short courses should enable the students to base their teaching on practical applications when they go into the schools.

Nottingham Regional College of Technology is one of five technical colleges-the others are John Dalton College, Manchester, Sunderland Technical College, Barking Regional College of Technology and North Western. Polytechnic-which are now running courses for the Certificate of Education. Previously these three year courses could only be taken at Colleges of Education. The Principal Lecturer, in charge of the science courses at Nottingham, is Dr Michael Bassey, who will be remembered for his trenchant criticisms of school science syllabuses at the British Association. meeting in 1961 .

\section{More Cancer Research}

A NEW research block consisting of laboratories for Tumour Immunology and Radiobiology was opened at Sutton, Surrey, on September 27. The unit is part of the Chester Beatty Research Institute, and the $£ 150,000$ it cost has come from the Napier Trust, the British Empire Cancer Campaign, the Medical Research Council and other donations. Block $\mathrm{X}$, as it is called, has been operational since June, only 17 months after the idea for such a unit was suggested. Because the unit is alongside the Sutton branch of the Royal Marsden Hospital, it is hoped that any positive results that are obtained will be speedily applied.

Work has been going on for some time on various forms of immunotherapy, and in particular the treatment of primary sarcomata by injection of either immunized lymphocytes or of immunized cancer cells, that is, cells taken from the tumour, after removal by surgery, and rendered "sterile" by irradiation. Some of the impetus for the new research unit has come from research described earlier this year by Alexander, Delorme, Hamilton and Hall (Nature, 213, 569). Evidence has been found in animals of host resistance to tumours, and it is hoped that by boosting this reaction by the injection of immune lymphocytes it will be possible to provide some control. This form of treatment would be particularly important after surgery.

Under some conditions this treatment has proved successful in experimental animals, but it is emphasized by the staff of the new unit that experience of this treatment is too limited for any definite conclusions to be drawn. The mechanism of the cytotoxic action of lymphocytes is also being studied.

American workers S. H. Nadler and G. E. Moore have also carried out transplant experiments in which tumours from two patients were transplanted to each other and after 10-14 days lymphocytes from each patient were transfused back to the other to fight the original growth. In several cases remission of the cancer for considerable lengths of time has occurred. This method of treatment is also being considered for investigation at the new unit.

\section{Refining Steel}

Electro-slaG Refining Technology, the British Iron and Steel Research Association's first development unit which was formed to exploit the electro-slag refining process, has fully justified its existence in its 15 months of operation on a commercial basis. It has recorded widespread use of its hire and contract facilities and has been responsible for a number of technical developments. Five plant manufacturers have entered into agreements with ESRT, and have installed or are installing fourteen plants with ingot producing capacities ranging from 8 to 36 in. The unit has also supplied. 250 ingots to some twenty-five customers, covering a range of thirty-five alloys. The ingots have enabled customers to evaluate the electroslag refining process. 224 ingots have been made on a miniature plant in thirty-eight individual contract evaluation programmes for fourteen clients. As a result of these studies, techniques have been developed for production melting of many alloys both in Britain and overseas.

Electro-slag refining is as secondary refining process 